\title{
A MEDICINA BRASILEIRA NO SÉCULO XIX: UN BALANÇO HISTORIOGRÁFICO
}

\author{
Flavio Coelho Edler \\ Pesquisador da Casa de Oswaldo Cruz - Fiocruz - Avda. Brasil 4365 \\ Río de Janeiro - R. J. 21040-360 (Brasil)
}

\section{RESUMEN}

Se presenta un balance historiográfico de la medicina brasileña del siglo XIX. El análisis se concentra en los estudios pioneros y contemporáneos, cuyas perspectivas constituyeron marcos significativos en el esfuerzo de interpretación histórica del campo médico en el período señalado.

\section{SUMMARY}

An historiographical survey of the brasilian medicine in the $\mathrm{XIX}^{\text {th }}$ century is presented. The focus is directed to pioneer and contemporary studies which are considered as landmarks in the historical understanding of the medicine field for that period.

Na literatura brasileira em História das Ciências relativa ao século XIX, os saberes, práticas, instituições, valores e personalidades do mundo médico ocupam um lugar privilegiado. Tal fato explica-se, em parte, pelo alto grau de institucionalidade logrado pela medicina acadêmica quando comparada a outros ramos científicos da época. Neste sentido, a situação brasileira harmoniza-se com a trajetória típica dos países de passado colonial, onde os médicos costumam formar o primeiro grupo profissional a dominar um sistema perito de base científica.

Como contribuição a esta coletânea, apresentaremos uma revisão crítica dos diferentes olhares projetados por estudiosos, cujas perspectivas constituíram marcos significativos no esforço de interpretação histórica do campo médico no período assinalado. Tal balanço historiográfico compreenderá quatro partes: inicialmente, apreciaremos a produção mais significativa da literatura pioneira, cuja particularidade é a homogeneidade do enfoque com que abordou os diversos temas do passado médico nacional; em seguida, discutiremos os critérios de periodização utilizados pelos historiadores que pretenderam caracterizar o período; avaliaremos, em seguida, a contribuição específica de alguns estudos de inspiração foucauldiana que tiveram um papel decisivo na redefinição dos problemas e dos aportes conceituais sobre 


\section{FLAVIO COELHO EDLER}

nosso assunto. Os trabalhos recentes, que possuem grande diversidade não apenas no tratamento conceitual, mas também quanto ao objeto e à metodologia, serão apresentados e analisados por último.

\section{A LITERATURA PIONEIRA}

Os estudos pioneiros sobre a medicina oitocentista foram escritos quase exclusivamente por médicos voltados para o passado de sua profissão com a perspectiva de estabelecer uma certa memória que conduzia inexoravelmente à celebração da medicina vigente. Nestes estudos, fatos, personagens, e instituições do passado encontram-se articulados em narrativas que buscam estabelecer um contraste com crenças e valores corroborados pela prática médica vigente, traduzindo uma concepção evolucionista das ciências médicas. Tal esquema teleológico apoia-se, geralmente, na armadilha representada pela noção hipostática de precursores - espíritos clarividentes atuando sob um pano de fundo dogmático e tradicionalista.

Tal simplismo metodológico não impediu que alguns destes estudiosos produzissem análises circunstanciadas das relações que se teceram entre a medicina oficial e aquela sociedade senhorial e escravista. Diferentes conjunturas foram assim demarcadas, iluminando-se as articulações entre conhecimentos e práticas médicas, mediados pelas instituições. Em contraste com a tendência européia dominante no mesmo período, embora ambas estivessem marcadas pela démarche positivista e triunfalista, não se encontram, aquí, aquelas sínteses que apresentam as contribuições médico-científicas originais mais ou menos dispostas como uma marcha progressiva do intelecto humano. Isto porque raras e periféricas foram as contribuições dos médicos do Império ao manancial técnico e teórico validado pelo saber médico europeu ${ }^{1}$.

Este embargo a uma história puramente intelectual da medicina brasileira conduziu a literatura pioneira a dedicar-se aos aspectos mais palpáveis de nossa vida médica. As instituições médicas foram, deste modo, seu posto de observação prioritário. Destacam-se, assim, os estudos sobre o ensino médico (MAGALHÃES, 1932; TORRES, 1952) a Academia Nacional de Medicina (SILVA, 1929), os médicos e cirurgiões da Imperial Câmara (VASCONCELLOS, 1964), a Escola Tropicalista Baiana (CONI, 1952), a assistência médica hospitalar (ARAúJO, 1982) e o serviço de saúde do Exército (Silva, 1958). Dentre os estudos biográficos, merecem menção os trabalhos de Fernandes (1982), Sattamini-Duarte (1957) e Gomes (1957). Várias miscelâneas resgataram aspectos variados da história da medicina e da farmácia no século XIX (ARAÚJO,1979; NAVA, 1947, 1949; RibEIRO, 1940, PEDrosA et al., 1984).

1 Exceção à esta regra é o livro de Freitas (1935), onde são apresentados os estudos originais realizados durante o período colonial e monárquico sobre as doenças africanas importadas para o Brasil juntamente com o tráfico de escravos. 


\section{A MEDICINA BRASILEIRA NO SÉCULO XIX: UN BALANÇO HISTORIOGRÁFICO}

Dentre os que buscaram traçar uma síntese do período, o estudo mais abrangente e representativo foi realizado por Santos Filho (1977; 1991), em sua enciclopédica História Geral da Medicina Brasileira.

Outra referência obrigatória, são os estudos desenvolvidos pelos médicos que se organizaram en torno da Revista Brasileira de Historia da Medicina (1949-1970)2. A fabricacão de tradicões, filiacões e genealogias com um passado médico idealizado em termos de uma progressiva afirmacão de valores e práticas científicas, bem como a criacão de uma mitologia histórica em torno da "natural" identidade da medicina como arte liberal, sacerdócio, etc... têm estreita relação com a maneira pela qual os médicos daquele período percebiam sua inscrição num mundo social que começava a ameaçar seu status quo. Seu principal propósito era reforçar a identidade liberal da medicina, então ameaçada pela progressiva diferenciação em termos de prestígio e renda que a categoria começava a experimentar, em fins da década de 1940.

\section{PERIODIZAÇÃO: A HERANÇA POSITIVISTA}

Um denominador comum aos estudos clássicos é o critério de periodização da medicina oitocentista, cuja complexa trama de teorias etiológicas e práticas curativas e terapêuticas foi abstraída sob a forma de uma dicotomia entre espíritos presos a especulações metafísicas, retóricos e anti-científicos versus espíritos científicos. $\mathrm{O}$ saber médico dominante estaria supostamente fundado no antigo paradigma galênico, ou em variantes neo-hipocráticas apresentadas como um conjunto eclético de conhecimentos acumulados sobre fenômenos mórbidos e vitais. Tal saber foi avaliado como um amálgama de preconceitos difusos de cunho irracional e dogmático. Os médicos brasileiros do século XIX teriam, nesta versão, especial aversão à observação metódica e à experimentação científica.

Esta distinção entre uma etapa predominantemente especulativa do saber médico oficial, seguida por outra, científica, fundada em "fatos positivos" e no "método experimental", é encontrada, por exemplo, na obra paradigmática de Santos Filho (op. cit.). $\mathrm{O}$ segundo volume, dedicado inteiramente ao século XIX, denomina-se "medicina pré-científica"'. Como outros autores, ele procura demarcar uma ruptura na evolução do saber médico, através de um recurso básico: de um lado foram colocados os mé-

2 Esse órgão do desaparecido Instituto Brasileiro de História da Medicina foi protagonista de um amplo movimento corporativo visando a criação da disciplina "História da Medicina e Deontologia Médica" nas faculdades de medicina, favorecendo, destarte, a produção de vasta série de estudos históricos originais.

3 Tal fase inicia-se em 1808, com a criação das primeiras escolas médico-cirúrgicas, e termina em fins do século XIX, com a criação dos primeiros institutos de pesquisa em medicina experimental e as bem sucedidas reformas sanitárias comandadas por Oswaldo Cruz 
dicos que defendiam as etiologias ambientalistas e rejeitavam as etiologias parasitárias, em especial a teoria pastoriana das doenças; do outro, seus defensores. Como prova cabal estes autores dispõem de toda a mitologia construída em torno de Oswaldo Cruz (1872-1917) e seus detratores - "espíritos dogmáticos", "positivistas adeptos da Religião da Humanidade", "inimigos da razão civilizadora", "viúvos da velha ordem Monárquica", etc. Outra prova freqüentemente referida seria a suposta rejeição das instituições médicas oficiais.- as Faculdades de medicina da Corte e de Salvador, e a Academia Imperial de Medicina e a Junta Central de Higiene Pública aos trabalhos experimentais no campo da helmintologia médica, publicados em 1866 pelo Dr. Otto Wucherer (1820-1873) na Gazeta Médica da Bahia. Verdadeiro tour de force foi feito por memorialistas e historiadores clássicos que se empenharam em salvar do naufrágio histórico alguns dos mais célebres médicos do Império que polemizaram contra os sectários da teoria microbiana das doenças (NAVA, 1947; FERNANDES, 1982).

Parte da produção acadêmica atual, apesar de rejeitar formalmente as narrativas históricas estruturadas nos marcos acima delineados, encontrou dificuldade para se desvencilhar da herança positivista inerente ao critério de periodização dos estudos pioneiros. Luz (1982) e Stepan (1976), autoras que tiveram grande influência renovadora no estudos sobre nosso passado médico, embora tenham estabelecido orientações teóricas distintas em suas investigações, aceitaram tacitamente a criação do Instituto Oswaldo Cruz, na primeira década de nosso século, como o momento de ruptura com os valores e práticas "anti-científicos" herdados da medicina do Império.

Stepan, cujo ponto de vista é orientado pelas obras de Merton (1970) e BenDavid (1971) em sociologia da ciência, estudou a gênese do primeiro instituto brasileiro de pesquisa em patologia experimental, o Instituto Oswaldo Cruz. Neste trabalho apresenta um esboço da prática clínica e da saúde pública no século XIX, que serve como contraponto à análise das ações transformadoras dos médicos-cientistas e sanitaristas durante a chamada República Velha (1889-1930). O preconceito em relação às instituições científicas do Império é inerente ao seu projeto de estudar "um ponto na história do Brasil onde tivesse ocorrido algum rompimento com a indiferença tradicional pela ciência, e no qual a ciência começou a ser investigada com certo grau de sucesso"(STEPAN, op. cit.: 19).

Luz, em seu livro sobre a Medicina e a Ordem Política Brasileira, desenvolve uma interpretação bastante controvertida sobre a dinâmica entre as instituições culturais e os saberes médicos no Segundo Reinado. Partindo de uma perspectiva construtivista radical, ela iria sustentar que os modelos científicos reproduzidos pelas instituições do Império vinculavam-se funcionalmente à origem social e às referências políticas dos movimentos que se organizavam em torno da questão da saúde. A partir de um marco teórico inspirado na obra clássica de Rosen (1958), em Foucault (1979) e numa leitura estruturalista de Gramsci (1968), as instituições médicas foram 
descritas como portadoras de projetos antagônicos de política sanitária, que expressariam uma clivagem de interesses entre as classes sociais dominantes na sociedade brasileira de então. A categoria de intelectual orgânico permitiu-lhe estabelecer os vínculos estruturais entre os projetos de política sanitária realizados pelos médicos higienistas e os interesses sociais dominantes. $\mathrm{O}$ esquema proposto interpreta a teoria miasmática sobre a causa das doenças como hegemônica nos aparelhos ideológicos do Estado a Academia Imperial de Medicina, a Junta Central de Higiene pública e as faculdades de medicina - posto que ligada aos interesses escravistas do capital agro-exportador. O outro modelo de medicina "experimental e biologicista", centrado numa etiologia ontológica, defendido pelos médicos parasitologistas que se articularam em torno da Gazeta Médica da Bahia (1866-1915), não encontraria acolhida nas instituições oficiais, revelando a posição subalterna da burguesia industrial baiana a que estes médicosintelectuais-orgânicos estariam vinculados (LuZ, op. cit.: 129-130). A caracterização de uma fase supostamente não científica da medicina brasileira impõe-se como decorrência de sua visão estrutural que previa a priori uma homologia entre a estrutura social e as instituições médicas do Império, "reprodutoras de uma forma précapitalista de visão de mundo e de dominação social" (LUZ, op. cit.: 129). Na mesma linha de argumentação reprodutivista encontra-se Garcia (1989), cuja tese sustenta que as dificuldades de implantação da Fisiologia Experimental no Brasil do século XIX deviam-se ao fato de que "os problemas da transformação da energia humana não eram considerados importantes (...), porque a força de trabalho era abundante, e o que se impunha era estudar as doenças que diminuíam a quantidade de trabalho que se prestava por unidade de tempo." (GARCIA, 1989: 142).

Não obstante o mérito de explorar novos modelos interpretativos sobre as relações entre a medicina e o Estado naquele contexto, a utilização de princípios explicativos muito gerais e a ausência de estudos históricos monográficos conduziu estes autores a sujeitar a pouca documentação pesquisada às exigências de uma interpretação totalizadora. Sem estabelecer novas evidências empíricas, estes trabalhos revisionistas e muitas vezes iconoclastas serviram-se dos mesmos marcos cronológicos levantados pelos estudos pioneiros. Ao invés de uma refutação da tese estabelecida pela historiografia clássica, articulou-se analiticamente de um modo diverso os termos do corte, reproduzindo de forma acrítica a demarcação positivista que se pretendia combater.

\section{A INFLUÊNCIA DE FOUCAULT}

Além do trabalho de Luz, outros dois livros que lhe foram contemporâneos, constituíram a primeira inflexão na pauta definida pelos estudos clássicos de história da medicina: "Danação da Norma: Medicina Social e a Constituição da Psiquiatria 


\section{FLAVIO COELHO EDLER}

no Brasil" (MACHADO et alii, 1978) e "Ordem médica e Norma Familiar" (COSTA, 1979). Estes trabalhos compartilhavam não apenas a mesma matriz intelectual - o pensamento foucauldiano seria o denominador comum - e o corte temático - a problemática de correlacionar a produção do pensamento médico com o processo de constituição do Estado brasileiro - mas também a ambição de contribuir para uma crítica do presente a partir de um diagnóstico histórico que auxiliasse na denúncia das formas de poder que se antepunham à emergência da plena cidadania democrática. Inauguraram, assim, uma nova tradição analítica, não apenas por romperem com a auto-imagem que a medicina forjara de si mesma, mas, principalmente, por introduzirem nova trama conceitual com a pretensão de evidenciar os nexos sociológicos, políticos, epistemológicos e econômicos que articularam historicamente o saber médico com o exercício de variadas formas de poder e dominação social.

$\mathrm{O}$ livro de Machado dedica-se à desvendar a gênese das instituições psiquiátricas na sociedade capitalista brasileira. A recusa da tradicional historiografia fática e exegética do saber psiquiátrico, que caucionava a versão humanista e racional das instituições asilares, é reforçada pela descoberta de suas raízes político-higiênicas. A conceito de medicalização da sociedade permitiu-lhe descrever as relações entre os saberes médicos e as práticas políticas da sociedade inclusiva não como uma justaposição ou exterioridade, mas como imanência. Destacou-se, assim, o papel jogado pela medicina na disciplinarização da população urbana do Império. Através de um conjunto de teorias, políticas e práticas que se aplicavam à saúde e bem-estar da população, apreendido pelo conceito de polícia médica, Machado analisou um tipo apoio científico que teria sido indispensável não só à constituição de uma ordem prévia ao desenvolvimento do capitalismo, como ao exercício de poder do Estado.

A reificação do instrumental teórico foucauldiano, aplicado sem mediações à sociedade patriarcal e escravista brasileira foi posteriormente criticada pela carência de base empírica (CARVALHO \& LIMA, 1992; EDLER, 1996, FERREIRA, 1996). Ao explorar as relações entre a prática médica e as instâncias de poder estatal que se forjaram na sociedade pós-colonial, Machado impôs-se a tarefa de delinear uma descontinuidade objetal: medicina social versus medicina individual. A primazia das questões higiênicas, a partir do século XIX, que inaugurariam todo um conjunto de tecnologias de controle e disciplina do corpo, expressaria o deslocamento da preocupação médica da doença em direção à saúde; da prática clínica, ligada aos métodos individualizados de cura, para as medidas de controle coletivo, que priorizariam as regras sociais de prevenção. O "médico político" lutaria, desde então, pelo "controle sanitário da sociedade". Ao incorporar a cidade e a população ao campo do saber médico a medicina teria se libertado da tutela jurídico-administrativa herdada da colônia, aliando-se ao novo sistema contra a antiga ordem colonial.

Tomando como dado relevante da realidade social o que não passava de um projeto defendido por segmentos da corporação médica, e com expressão apenas resi- 


\section{A MEDICINA BRASILEIRA NO SÉCULO XIX: UN BALANÇO HISTORIOGRÁFICO}

dual nas instituições que sustentavam o poder da classe senhorial, este autor vai afirmar equivocadamente que a partir de 1850, quando se criou a Junta Central de Higiene Pública, o poder das câmaras municipais foi esvaziado. Desde então, " $a$ medicina [ocuparia] uma posição central no saber, e seus braços [sustentariam] a sociedade. $O$ projeto médico defende e justifica a sociedade medicalizada, lutando por uma posição em que o Direito, a Educação, a política e a moral seriam condicionadas à seu saber" (MACHADO, op. cit.: 194).

A obra de Costa (op. cit.) buscou aplicar ao estudo da formação da família burguesa brasileira, a tese, proposta por Foucault (1976), de que o século XIX assistiu à invasão progressiva do espaço da lei pela tecnologia da norma. Seguindo a trilha aberta por Donzelot (1977), para quem o Estado moderno, voltado para o desenvolvimento industrial, realizou um prévio controle demográfico e político da população através dos instrumentos criados pela medicina higiênica doméstica, Costa propôs uma releitura do processo de dissolução dos laços patriarcais herdados da fase colonial. Sua tese foi conduzida ao longo de uma trama argumentativa complexa, que fez uso de uma rica documentação original ${ }^{4}$ ao dialogar com alguns dos mais autorizados intérpretes da sociedade pós-colonial. O período joanino (1808-1821) marcaria o início da trajetória de normalização médica da família patriarcal, operando em estreita correspondência com o desenvolvimento urbano e a construção do Estado nacional. Neste trabalho os médicos higienistas procuraram modificar a conduta física, intelectual, moral, sexual e social do núcleo familiar com vistas à sua adaptação ao sistema econômico e político. Pouco a pouco "o confessor $e$ o filho-padre foram sendo substituídos por essa figura carinhosa e firme, doce e tirânica do médico-defamília" (COSTA, op. cit.: 77). A invenção desses personagens higienizados levou o Estado a reconsiderar a estratégia colonial de combate á família insular através de uma ética estritamente punitiva e legal. Para opor-se às regras de casta do senhoriato colonial a medicina pôs em prática variadas "táticas de assalto à família". No decurso do Segundo Reinado (1841-1889) a higiene familiar teria fracionado as velhas relações de casta, religião e propriedade, preparando a família para acomodar-se e participar na criação dos valores de classe, corpo, raça e individualismo característicos do Estado burguês. Ao mesmo tempo em que abandonou o casulo patriarcal da Casa Grande e inaugurou novos espaços de sociabilidade mundana, a família de elite foi se tornando mais intimista. Ao criar uma gama variada de interesses que opunham adultos e crianças, homens e mulheres, pais e filhos, recém-nascidos e adolescentes, etc., a ordem médica - conceito chave - teria se imposto à vontade monolítica do poder paterno.

\footnotetext{
4 As teses de formatura e de concurso das faculdades de medicina da Corte e de Salvador.
} 


\section{FLAVIO COELHO EDLER}

\section{OS ESTUDOS RECENTES}

Uma decorrência dos trabalhos acima referidos foi a aproximação de historiadores e cientistas sociais aos temas do passado médico nacional. Desenvolvendo aspectos particulares das teses acima esboçadas, ou partindo de orientações teóricometodológicas diferentes, surgiu, ao longo dos últimos quinze anos, toda uma literatura que apostou no maior controle das hipóteses históricas construídas a partir de recortes temáticos menos abrangentes 5 . Inegável, também, tem sido a influência dos estudos sociais da ciência, pós-kuhnianos, que recusaram sua antiga imagem de sistema autônomo guiado por uma lógica particular de desenvolvimento. $\mathrm{O}$ contexto histórico de produção e difusão dos saberes foi reabilitado não mais como o espaço da hagiografia dos cientistas, do pitoresco ou do anedótico, tampouco como determinante macro-sociológico que postula a priori um certo nexo estrutural entre ciência e sociedade. Podemos resumir, nas palavras de uma autora, que será referida adiante, as idéias-chaves que informam genericamente as novas metodologias: "uma rejeição das explicações simplistas que concebem a ciência médica puramente em termos de um avanço racional do conhecimento; aliada ao reconhecimento do estreito relacionamento entre os fatos biológicos e a construção social das idéias médicas" (PEARD, 1990) ${ }^{6}$.

Faremos uma apresentação sumária de alguns dos principais estudos históricos, indicando, quando necessário, outros autores que tenham contribuições pontuais sobre o assunto. Seguiremos em ordem cronológica de publicação, sem a preocupação de definir uma tipologia prévia. $O$ leitor estrangeiro deve ter em mente que os alinhamentos eventuais, que essas análises possam ter com certas vertentes da historiografia da medicina contemporânea, não permitem um enquadramento exclusivo. Os rótulos possíveis - história das doenças, história da profissão médica, história da saúde pública, história das teorias médicas, etc. - além de sempre precários, teriam que expressar a vigência de tradições de pesquisa ou linhas programáticas consolidadas?

Peard (1990) desenvolveu um estudo aprofundado sobre um grupo de médicos baianos, que na segunda metade do século XIX, inicialmente fora do ambiente institucional, ajudaram a disseminar novas idéias sobre saúde e doença no Brasil. A Escola Tropicalista Baiana, como eram chamados, ficou conhecida por seus trabalhos

\footnotetext{
5 Geralmente apresentados como teses em institutos de pós-graduação, estes estudos, quase sempre monográficos, resultam do esforço de abertura a novos objetos e abordagens teóricas, aliado a um maior rigor metodológico no trabalho com as fontes.

6 A crítica à neutralidade do chamado método científico "universal" e "a-histórico" tornou o estudo do empreendimento científico largamente permeável às vicissitudes do humano e do social.

7 Apenas duas instituições nacionais têm constituído programas regulares de pesquisa em História da Medicina: o Centro de Documentação e Pesquisa Histórica da Casa de Oswaldo Cruz -FIOCRUZ, e o Programa de pós-graduação do Instituto de Medicina Social - UERJ.
} 


\section{A MEDICINA BRASILEIRA NO SÉCULO XIX: UN BALANÇO HISTORIOGRÁFICO}

sobre beribéri, ancilostomíase, filariose e ainhum - doenças associadas ao clima tropical. Em contraste com as idéias de medicina tropical desenvolvidas pelas potências coloniais européias, Peard vai postular que os tropicalistas forjaram sua própria definição de medicina tropical, baseados na crença otimista sobre a possibilidade de um lugar para o Brasil ao lado das nações civilizadas, apesar de seu clima e do povo miscigenado. Deste modo, ela privilegiou dois ângulos de análise. Primeiramente, o processo de constituição da base institucional, isto é, a trajetória que conduziu este grupo da posição inicial de outsiders, críticos ao ambiente médico baiano, até sua total assimilação pela comunidade médica. Em seguida, num patamar mais próximo da história cultural, ela examinou como as idéias médicas européias de cunho raciológico e climatológico foram adaptadas ao contexto do Império brasileiro. Há, ainda, um capítulo dedicado às relações entre a medicina e as mulheres naquela sociedade.

Um dos méritos do trabalho foi inverter o sentido do caminho geralmente trilhado pelos historiadores, que analisam a constituição da medicina tropical a partir do ponto de vista europeu. Ao focalizar os interesses dos médicos que viviam num país tropical, a problema da gênese desta disciplina tornou-se mais complexo e ambíguo. O estereótipo dos trópicos como região deletéria para o europeu, bastante disseminada desde o século XVIII, conduziu a produção de um conhecimento original por parte dos médicos brasileiros, em bases não formalmente institucionalizadas, bem antes do advento das teorias parasitológicas das doenças. Teorias raciais, como o poligenismo, bastante vulgarizado nos Estados Unidos, foram rejeitadas por uma sociedade miscigenada, onde muitos médicos eram mulatos ou negros (PEARD, op. cit.:1 86-203). Por outro lado, ainda que não declaradamente lamarckistas, os médicos da Bahia, valorizavam a maleabilidade e adaptabilidade dos seres humanos, em contraposição ao determinismo climático amplo. "Esta concepção da natureza humana possibilitava que os tropicalistas desenvolvessem um modelo etiológico flexível que punha ênfasé no papel dos médicos na preservação e recuperação da saúde de seus pacientes" (PEARD, op. cit.: 205). Em contraste com as conclusões anteriores de Goodyear (1982), Peard demonstra inequivocamente que a etiologia ambientalista não conduzia necessariamente a um determinismo pessimista sobre o clima tropical por parte dos médicos brasileiros.

Um aspecto problemático do texto de Peard reside no argumento da originalidade do enfoque dos tropicalistas, em contraste com o meio médico brasileiro. A existência de uma Escola Tropicalista Baiana foi postulada originalmente por Coni (1952) ao estudar o grupo de médicos que se organizavam em torno da Gazeta médica da Bahia (1866-1890). A fábula, inventada por Coni (op,cit.), de que a Academia Imperial de Medicina teria rejeitado, sem prévio exame e por meio de voto, as conclusões das pesquisas de Wucherer (1820-1873) - líder do grupo baiano - sobre a etiologia parasitária da hipoemia intertropical (ancilostomíase), foi por ela aceita sem revisão (PEARD, op. cit.:155). Isto a levou a apostar da idéia da existência de uma rivalidade 


\section{FLAVIO COELHO EDLER}

regional entre os médicos do Império. Estudos posteriores (EDLER, 1992; BENCHIMOL, 1996) trouxeram diversas evidências de que na Corte o ambiente médico estava também permeado pelas mesmas preocupações em se criar um conhecimento original sobre as doenças epidêmicas. Várias sociedades e periódicos médicos do Rio de Janeiro postulavam a necessidade de se incrementarem as pesquisas sobre os nossos males, visando reabilitar a imagem insalubre do Império perante as nações européias. O espectro da "Escola Tropicalista" impediu-lhe de perceber a extensão com que as novas idéias sobre as etiologias parasitárias se amalgamaram com as etiologias climáticas e racistas, fecundando o solo médico brasileiro, a partir da década de 1870.

Edler (1992) focalizou as reformas do ensino médico e a trajetória que levou à profissionalização da medicina acadêmica na Corte do Rio de Janeiro, durante o reinado de Pedro II (1842-1889). Sua análise buscou confrontar as tradicionais dicotomias que opunham uma medicina "científica" do período republicano a uma medicina "especulativa" do Império, revendo os conceitos reificados de "ciência", "médico" e "medicina" vigentes na historiografia. O marco temporal foi definido pelas reformas da Faculdade de Medicina do Rio de Janeiro ocorridas em 1854 e 1884, que resultaram em mudanças nos Estatutos. A primeira, orientada pelo modelo anatomoclínico, inspirava-se no arranjo centralizador das instituições médicas parisienses. A segunda, incorporava as disciplinas de laboratório e seguia o figurino germânico, traduzindo-se nas palavras de ordem "ensino prático" e "ensino livre". O estudo pretendeu, caracterizar duas fases distintas no processo de profissionalização da medicina no século XIX. A década de 1870 foi retratada como um momento de inflexão no relacionamento entre a corporação médica e a alta burocracia imperial. Uma nova representação sobre os fundamentos do saber médico, expressa pela noção de medicina experimental, pôs fim à fase de maior dissensão entre os esculápios, que caracterizara as décadas anteriores, dificultando as estratégias de profissionalização (EDLER, op. cit.: 66-70). O conceito de elite médica, procurou descrever as ações das lideranças corporativas que lutavam para redefinir os espaços institucionais e almejavam se impor como porta-vozes dos variados interesses corporativos. Num plano mais genérico, Edler constatou que era possível lhes atribuir, coletivamente, um papel chave na construção das representações clássicas da medicina como atividade liberal, autônoma e portadora de valores meritocráticos consolidados por uma ética de serviço o que desencadeou vários conflitos com a burocracia imperial. Uma ética estritamente clientelista regia os laços de dependência pessoal entre o conjunto da população livre e as oligarquias senhoriais. A discussão da pauta das reformas do ensino, na década de 1870, revelou que, para além dos compromissos tácitos em torno das prerrogativas da profissão, as elites médicas continuavam a divergir em vários pontos. Para analisar estas divergências, atenção especial foi dada ao periodismo médico na Corte. A imprensa médica mais que as instituições acadêmicas oficiais, asfixiadas pelos entraves 


\section{A MEDICINA BRASILEIRA NO SÉCULO XIX: UN BALANÇO HISTORIOGRÁFICO}

burocráticos impostos pela administração imperial, tornou-se o instrumento preponderante de propaganda e persuasão política dos grupos reformistas. Pondo os médicos brasileiros a par dos mais recentes trabalhos produzidos em todas as partes do Velho Mundo, a imprensa médica da Corte forçou a atualização do debate científico em torno das pesquisas voltadas para o estudo da nosologia e terapêuticas nacionais, ajudando, igualmente, a difundir um diagnóstico negativo sobre as instituições formalmente destinadas à formação e controle de exercício da medicina (EDLER, 1992, 168-184). Quando os médicos do Império, majoritariamente defensores do paradigma climatológico, foram confrontados com as teorias parasitológicas das doenças, a fronteira entre as categorias de "charlatão" e "médico", entre "erro dogmático" e "verdade científica" começou a se mover. Isto ocorria num contexto em que a Medicina acadêmica buscava alcançar prestígio como sistema perito, visando a construção de um monopólio da autoridade científica frente a homeopatas e diversas outras categorias de curadores. Desta forma, a imprensa médica foi percebida como o espaço privilegiado de difusão das novas idéias, bem como arena de confronto e negociação político-epistemológica entre os grupos que defendiam credos científicos rivais. Edler argumentou que os periódicos médicos ajudaram a romper com o monopólio do discurso ex cathedra proferido pelos professores ou membros da Academia Imperial de Medicina - instâncias legitimadas e legitimadoras da medicina oficial, evitando, ao mesmo tempo, que as dissensões ultrapassassem os limites da corporação.

Embora Edler tenha reconhecido alguns dos elementos que compunham o quadro de desprestígio social, vinculando-o às controvérsias sobre as bases do saber médico em meados do século passado, os estudos posteriores de Sayd (1995) e Ferreira (1996) ampliaram muito a compreensão deste problema. A investigação de Sayd sobre a terapêutica no pensamento médico brasileiro do século XIX tornou muito mais claro o panorama de ceticismo terapêutico que permeou o ambiente médico oficial (SAYD, op. cit.: 50-57). Enquanto Ferreira - analisado adiante - retratou as disputas, sequer vislumbradas por Edler, que ocorreram entre os médicos e os antigos cirurgiões, na primeira metade do século XIX.

A utilização de periódicos médicos foi também privilegiada por Schwarcs (1993), ao estudar as relações entre cientistas, instituições e a questão racial no Brasil, entre 1870 e 1930. Partindo de uma perspectiva construtivista da história das ciências, ela pôs em foco "tanto a dinâmica de reconstrução de conceitos e modelos como o contexto em que essas teorias se inserem", visando compreender "como o argumento racial foi política e historicamente construído nesse contexto, assim como o conceito de raça, que além de sua definição biológica acabou recebendo uma interpretação sobretudo social" (SCHWARCS, 1993: 17). A análise da Gazeta Médica da Bahia e do Brazil Médico, nos anos 1890, permitiu-lhe correlacionar a produção do saber médico com o contexto institucional da Bahia e do Rio de Janeiro, respectivamente. Para ela, os médicos da Faculdade do Rio de Janeiro buscavam sua originalidade e 


\section{FLAVIO COELHO EDLER}

identidade na descoberta de doenças tropicais. Enquanto os médico baianos fariam um movimento análogo, ao entender o cruzamento racial como o nosso grande mal ${ }^{8}$ (SCHWARCS: op. cit.: 190).

O estudo de Ferreira (1996) sobre os periódicos médicos brasileiros na primeira metade do século XIX, trouxe grande contribuição para a compreensão das disputas políticas e institucionais que presidiram a institucionalização da medicina moderna no contexto cultural da ilustração luso-brasileira - marcado pela concepção utilitarista da ciência, que impunha ao Estado um papel de protagonista na promoção das atividades científicas.

Tomando o periódico médico - ao lado da faculdade de medicina, do hospital e da Academia médica - como instituição científica típica daquela fase de configuração do campo médico em bases modernas, Ferreira pôs em evidência as disputas entre os cirurgiões e os médicos, bem como as estratégias utilizadas por estes no sentido de limitar o conjunto de prerrogativas institucionais herdadas por aqueles. A "medicina dos cirurgiões" seria, paulatinamente, subjugada pelo projeto higienista, posto em prática pelos médicos organizados em torno da Sociedade de Medicina do Rio de Janeiro - embrião da Academia Imperial de Medicina. Apenas em 1848 um decreto legislativo poria fim às distinções entre cirurgiões e médicos. Este resultado revelou a presença social e força política dos cirurgiões portugueses, que instituíram as bases iniciais do ensino médico-cirúrgico e souberam defender seus privilégios, apesar das sucessivas derrotas frente ao modelo médico francês que acabou se impondo (FERREIRA, op. cit.: 51-67). Seguindo a trilha aberta por Kury (1994) e Silva (1978) sobre o papel da Higiene como paradigma civilizatório com fortes afinidades com o despotismo esclarecido, assumido por parte da elite intelectual brasileira, entre fins do século XVIII e início do XIX, Ferreira expôs, entretanto, seus limites políticos: " $a$ tradução dos princípios higienistas para o contexto natural e social brasileiro foi o maior êxito da Sociedade de Medicina do Rio de Janeiro. Ela não esteve à frente de um movimento higienista de ampla repercussão social; isso na verdade nunca existiu" (FERREIRA, op. cit.: 71). Coube aos cinco periódicos médicos deste período, vinculados ao projeto da Academia Imperial de Medicina, o papel de consolidar um primeiro diagnóstico sobre os males nacionais e de tornar o tema das doenças tropicais uma "questão obrigatória" para aquela geração de médicos brasileiros (FERREIRA, 1996: 99). Inscritos em um campo médico de características peculiares, onde a medicina era predominantemente praticada por cirurgiões de formação prática, desprovidos de hábitos acadêmicos, os periódicos médicos desse período teriam nas questões de higiene seu canal de contato com os problemas sociais (FERREIRA, op. cit.: 178-179). A maneira pela qual abordou a relação entre a Academia Imperial de Medicina e a

8 Sobre as teorias raciais desenvolvidas na Bahia pela Escola de Nina Rodrigues, ver os trabalhos de CORRÊA (1983) e PEARD (op. cit.) 
sociedade envolvente, guiando-se pelas biografias de seus fundadores e comparando suas trajetórias individuais, fez emergir um quadro dinâmico, onde os projetos iniciais se modificam ao interagirem no processo histórico. $\mathrm{O}$ que contrasta vivamente com o método descritivo de Machado (op. cit.), que, ao reforçar a coerência da $e s$ tratégia higienista, apagou todas as divergências internas, contradições, nuances e reveses sofridos pelos esculápios naquele período.

Chalhoub, um historiador atento ao cotidiano das classes populares, realizou recentemente uma vigorosa contribuição para a recuperação de aspectos das concepções populares sobre doença e cura e sua relação com as práticas higiênicas oficiais, durante o século XIX. A preocupação inicial de sua pesquisa era reconstruir a experiência de negros escravos, libertos e livres em moradias populares coletivas no Rio de Janeiro, os chamados cortiços. A documentação o conduziu aos papéis da Junta Central de Higiene Pública. O alcance real das práticas higienistas e as respostas sociais às políticas de saúde pública tornaram-se preocupações intrínsecas ao seu projeto. Três hipóteses foram, então, construídas e meticulosamente esmiuçadas. A primeira, discorre sobre o conteúdo político do debate em torno da Febre Amarela. Para personagens eminentes do tempo de D. Pedro II, cortiços e epidemias de febre amarela eram indissociáveis. As "classes perigosas", o seriam duplamente "porque propagavam a doença e desafiavam as políticas de controle social do meio urbano" (CHAluob, 1996: 8). No decorrer da década de 1870, a Febre Amarela teria se tornado a questão central de saúde pública no Brasil, porque tal flagelo havia se constituído num dos principais obstáculos à realização do projeto político de substituição da trabalho escravo pelo mão de obra formada pela imigração de colonos europeus. A interdependência entre os problemas do aclimatamento, da Febre amarela, dos cortiços e da imigração européia, no contexto das transformações das relações de trabalho passou a ser postulada pelos esculápios da Corte. A crença generalizada era a de que a "praga amarela" exterminava predominantemente o europeu ainda não aclimatado, enquanto poupava o negro. Isto inviabilizava a aposta das elites no "branqueamento" do povo como solução aos entraves do progresso civilizatório, tal como formulavam diversas teorias racistas aceitas amplamente no ambiente intelectual cientificista da época.

Outra hipótese refere-se às raízes culturais negras de rejeição à vacina contra a Varíola, o que o levou a uma reinterpretação do famoso evento, ocorrido em 1904, na capital da República, cunhado pela historiografia como a "Revolta da Vacina". Questionando a idéia consolidada de que a obrigatoriedade da vacinação teria sido um pretexto para uma revolta que tinha outras motivações (SEVCENKO, 1984, CARVAlHo, 1987), Chalhuob (op. cit.) investe na hipótese de que haveria alguma tradição, valores ou experiências informando os atores populares da revolta. Isso deslocou sua análise para o serviço de vacinação antivariólica no Brasil, criado em 1804. O autor vai descortinando, pouco a pouco, todo o rico conteúdo cultural, dado 


\section{FLAVIO COELHO EDLER}

pelas religiões africanas, ao ritual de variolização. Emerge, ao mesmo tempo, o significado do medo e da recusa à técnica oficial de vacinação.

A terceira hipótese, que aparece como uma das conclusões de sua pesquisa, e se refere a um desdobramento daquilo que ele denomina "ideologia da higiene". Tal ideologia, amparada nos paradigmas do contágio e da infecção sobre as causas e os modos de propagação das doenças epidêmicas, formularia o diagnóstico de que "os hábitos dos moradores pobres eram nocivos à sociedade, e isto porque as habitações coletivas eram focos de irradiação de epidemias, além de, naturalmente, terrenos férteis para a propagação de vícios de todos os tipos" (CHALHOUB, op. cit.:29). Tal diagnóstico forneceu as bases para a intervenção no meio urbano, visando o controle social dos pobres. A administração competente agiria a partir de critérios técnicos, não políticos, cuja racionalidade seria supostamente extrínseca às desigualdades sociais urbanas. Não desconhecendo as críticas de Pilling (1978) dirigidas à interpretação clássica apresentada por Ackerknecht (1948) do debate entre contagionistas e anticontagionistas, Chalhub procurou explorar a hipótese de Cooter (1982) sobre as metáforas políticas presentes em ambas as teorias médicas. $O$ resultado a que chegou foi, entretanto, diametralmente oposto. Enquanto Cooter assevera que um dos sentidos principais da idéia de infecção foi fundamentar as tentativas de desqualificação ou expropriação de conhecimentos populares e práticas alternativas de cura ligadas às doenças transmissíveis, todo o argumento apresentado sobre as reações populares contra a vacinação antivariólica no Brasil, "sugerem que uma doença reconhecida como contagiosa pelo conhecimento médico do século passado esteve também no centro das lutas sociais em torno da interpretação das doenças e das práticas de cura" (CHALHUB, op. cit.: 176).

A febre amarela também serviu de fio condutor para que Benchimol (1996) pudesse estudar as primeiras gerações de bacteriologistas que atuaram na cidade do Rio de Janeiro, no último quarto do século XIX. Ao examinar os esforços que se fizeram para descobrir seu micróbio e um imunológico eficaz para prevenir ou curar a doença, ele mostra a ressonância internacional - rede internacional - e as implicações socio-econômicas das teorias e das práticas terapêuticas postuladas. $\mathrm{O}$ autor analisa, por último, as rupturas cognitivas e institucionais associadas à passagem da problemática etiológica para a do modo de transmissão. A escolha de Oswaldo Cruz para chefiar a saúde pública e a campanha contra a febre amarela no Rio é reexaminada à luz das experiências, dos erros e acertos das primeiras gerações de bacteriologistas que atuaram na cidade. Rompendo com a dicotomia internalismo versus externalismo, este trabalho demonstra como as disputas doutrinárias se entrelaçavam com a problemática do saneamento.

Influenciado pela abordagem feita por Latour (1979) em sociologia da inovação científica, em especial o alcance metodológico da tese da simetria, e pela análise elaborada por Warner (s.d.) sobre os critérios de prova científica em estudos bacte- 


\section{A MEDICINA BRASILEIRA NO SÉCULO XIX: UN BALANÇO HISTORIOGRÁFICO}

riológicos em fins do século XIX, Benchimol elaborou como hipótese que a ciência dos micróbios se converteu no polo mais dinâmico da medicina brasileira, por obra de postulantes de teorias etiológicas que acabaram sendo desqualificadas nos fóruns médicos internacionais. Desenrola-se, então, uma densa narrativa onde se articulam, na constituição do novo campo de investigação científica, as redes interpessoais, as relações econômicas, as coações políticas e institucionais e os constrangimentos cognitivos dos paradigmas.

Cabe, por fim, mencionar o trabalho de Luz (1996) sobre a Homeopatia no Brasil, desde sua introdução pelo Dr. Mure, adepto das idéias de Fourier que aqui chegou, na década de 1840, para fundar um falanstério. Embora tenha distinguido diferentes conjunturas do processo de institucionalização deste saber, ampliando muito o quadro descrito anteriormente por Novaes (1989), sua análise ainda permanece presa ao mesmo enquadramento maniqueísta. Enquanto o campo homeopático é descrito em toda sua espessura, evidenciando-se os diversos grupos que o compunham e almejavam liderá-lo, a medicina acadêmica é retratada com o mesmo perfil monolítico de seu estudo anterior (LUZ, 1982).

\section{BIBLIOGRAFÍA}

ACKERKNECHT, E. H. (1948) "Anticontagionism between 1821 and 1867", Bulletin of the History of Medicine, 22:562-593.

ARAúJo, A. R. de. (1982) A assistência médica hospitalar no Rio de Janeiro no século XIX. Rio de Janeiro, Ministério da Educação e Cultura, Concelho Federal de Cultura.

Araújo, C. da S. (1979) Fatos e Personagens da História da Medicina e da Farmácia no Brasil, Rio de Janeiro, Editora Continente Editorial.

BEN-DAvid, J. (1971) The scientist's role in society. Acomparative study, New Jersey, Prentice-Hall Inc.

BenChIMOL, J. L. (1996) Do Pasteur dos micróbios ao Pasteur dos Mosquitos: febre amarela no Rio de Janeiro (1880-1903), Niterói, Tese de doutoramento (Curso de Pós Graduação em História) Universidade Federal Fluminense.

Carvalho, M. A. R. de \& Lima, N. V. T. (1992) "O argumento Histórico nas análises de saúde coletiva" in FLEURY (org.) Saúde: Coletiva? Questionando a onipotência do social, Rio de Janeiro, Relume-Dumará.

CARvalho, J. M. de. (1987) Os Bestializados: o Rio de Janeiro e a República que não foi, São Paulo, Companhia das Letras.

Chalhuob, S. (1996) Cidade Fabril: cortiços e epidemias na Corte imperial, São Paulo, Companhia das Letras.

Coni, A. C. (1952) A Escola Tropicalista Baiana: Paterson, Wucherer, Silva Lima, Salvador, Tip. Beneditina. 


\section{FLAVIO COELHO EDLER}

COOTER, R. (1982) “Anticontagionism and History`s medical record. In WRIGHT, P., \& TREACHER, A. The problem of medical Knowledge: examining the social construction of medicine, Edimburgh, pp. 87-108.

CORRÊA, M. (1983) As ilusões da liberdade. A Escola de Nina Rodrigues e a antropologia no Brasil, São Paulo, tese de doutoramento, USP.

CostA, J. F. (1979) Ordem Médica e Norma Familiar, Rio de Janeiro, Edições Graal.

DONZELOT, J. (1977) La police des familles. Paris, Minuit.

EDLER, F. C. (1992) As Reformas do Ensino Médico e a Profissionalização da Medicina na Corte do Rio de Janeiro 1854-1884. Tese de mestrado, FFLCH-USP, Departamento de Pósgraduação em História, São Paulo.

EDLER, F. C. (1996) "O debate en torno da medicina experimental no segundo reinado". História, ciência, saúde-Manguinhos, III (2): 284-299, jul.-oct.

FERnANDES, R. (1982) O Conselheiro Jobim e o Espírito da Medicina de Seu Tempo, Brasília, Ed. do Senado Federal.

FERREIRA, L. O. (1996) O Nascimento de uma instituição científica: os periódicos médicos brasileiros da primeira metade do século XIX, tese de doutorado, FFLCH-USP, Dept ${ }^{\circ}$ de História, São Paulo.

Foucault, M. (1976) La volonté de savoir, Paris, Gallimard.

Foucault, M. (1979) Microfísica do Poder, Rio de Janeiro, Edições Graal.

Freitas, O. de. (1935) Doenças Africanas no Brasil, São Paulo, Editora Nacional.

García, J. C. (1989) Pensamento social e saúde na América Latina, São Paulo, Cortez.

Gomes, O. C. (1957) Manuel Vitorino Pereira, médico e cirurgião. Rio de Janeiro, Livraria Agir Editora.

GoODYEAR, J. D. (1982) Agents of Empire: portuguese doctors in colonial Brazil and the idea of tropical disease, Doctoral dissertation, Johns Hopkins University.

GramSCI, A. (1968) Os intelectuais e a organização da cultura, Rio de Janeiro, Civilização Brasileira.

LATOUR, B. \& WoOlgar, S. (1979) Laboratory Life. The social construction of scientific facts. California, Sage Publications, Inc.

LAtour, B. (1984) Les microbes. Guerre et paix suivi de irréductions. Paris, Editions A. M. Métaille.

LuZ, M. T. (1982) Medicina e ordem política brasileira: 1850-1930, Rio de Janeiro, Graal.

LuZ, M. T. (1996) A arte de curar versus a ciências das doenças, História da Homeopatia no Brasil, São Paulo, Ed. Dynamis.

KuHN, T. (1962) The stucture of scientific revolutions. Chicago, University of Chicago Press. 


\section{A MEDICINA BRASILEIRA NO SÉCULO XIX: UN BALANÇO HISTORIOGRÁFICO}

KURY, L. B. (1991) O Império dos miasmas: A Academia Imperial de Medicina (1830-1850), Niterói, Dissertação de mestrado, Pós-graduação em História - Universidade Federal Fluminense.

Machado, R., (1978) et al. Danação da Norma: medicina social e constituição da Psiquiatria no Brasil, Rio de Janeiro, Graal.

Magalhães, F de. (1932) O centenário da Faculdade de Medicina do Rio de Janeiro 18321932, Rio de Janeiro, Typ. A.B. Barthel.

MERTON, R. K. (1970) Science, technology and society in seventeenth Century England, New York, Harper and Row.

Nava, P. (1947) Território de Epidauro, Rio de Janeiro, C. Mendes Junior.

Nava, P. (1949) Capítulos da História da Medicina no Brasil, Rio de Janeiro, Brasil Médico Cirúrgico.

NovaEs, R. L. (1989) O tempo e a Ordem: sobre a Homeopatia. São Paulo, Cortez.

Peard, J. G. (1990) The Tropicalist School of Medicine of Bahia, Brazil, 1869-1889, Michigan, Columbia University.

Pedrosa, M. X. de V. (1984) et. al. Anais do Congresso de História do Segundo Reinado (Comissão científica) in Revista do Instituto Histórico e Geográfico Brasileiro, 2 vols, Rio de Janeiro.

Pelling, M. (1978) Cholera, fever and English medicine: 1825-1865. Oxford, Oxford University Press.

RosEn, G. (1958) A history of Public Health, Nova York, MD publications.

SAntos Filho, L. de C. (1977) História Geral da Medicina Brasileira I, São Paulo, EDUSP.

SAntos Filho, L. de C. (1991) História Geral da Medicina Brasileira II, São Paulo, EDUSP.

SatTamini-Duarte, O. (1957) Um Médico do Império (O doutor Torres Homem) 1837-1887, Rio de Janeiro, Irmãos Pongetti,.

SAYDE, J. D. (1995) Mediar, medicar, remediar. Terapêutica na medicina contemporânea: o pensamento médico brasileiro, Rio de Janeiro, Tese de Doutorado Pós-graduação do Instituto de Medicina Social - UERJ.

SCHWARCS, L. M. (1993) O Espetáculo das raças: Cientistas, instituições e questão racial no Brasil: 1870-1930, São Paulo, Companhia das Letras.

SEvCEnKo, N. (1984) A revolta da Vacina: Mentes insanas em corpos rebeldes. São Paulo, Brasiliense.

Silva, A. N. (1929) O centenário da Academia Nacional de Medicina do Rio de Janeiro 1829-1929, Rio de Janeiro, Imprensa Nacional.

Silva, A. L. da. (1958) O serviço de saúde do Exército Brasileiro, Rio de Janeiro, Biblioteca do Exército.

Silva M. B. N. da. (1978) Cultura e sociedade no Rio de Janeiro (1808-1821), São Paulo, Companhia Editora Nacional. 


\section{FLAVIO COELHO EDLER}

StEPan, N. (1976) Gênese e Evolução da Ciência Brasileira: Oswaldo Cruz e a Política de investigação Científica e Médica. , Rio de Janeiro, Artenova.

TORRES, O. (1952) Esboço histórico dos acontecimentos mais importantes da vida da Faculdade de Medicina da Bahia. 1808-1946, Salvador, Imprensa Vitória.

VASCONCELlos, V. J. (1964) "Médicos e cirurgiões da Imperial Câmara - reinados de Pedro I e Pedro II" in Revista dos Tribunais, Rio de Janeiro.

WARNER, M. (1985) "Hunting the yellow fever germ: the principle and practice of etiological proof in late nineteenth-century America" in Bulletin of the History of Medicine (59): 361-383. 